\title{
Properties of Proteus and Providence Strains Harbouring Recombinant Plasmids between P-lac Rldrd19 or R447b
}

\author{
By J. N. COETZEE \\ Department of Microbiology, University of Pretoria, \\ Republic of South Africa
}

(Received 22 May 1973)

SUMMAR Y

Recombinant plasmids between RIdrdI9 and P-lac and between R $447 \mathrm{~b}$ and $\mathrm{P}$-lac were produced by phage PL25 transductions of the respective $\mathrm{R}$ factors to Providence P29 strains harbouring P-lac. The P-lac $\overline{\mathrm{R} I d r d \mathrm{I} 9}$ (the superior line indicating the transduced $\mathrm{R}$ factor) recombinant plasmid transfers $l a c^{+}$and all determinants of the $\mathrm{R}$ factor to Proteus mirabilis strains and Escherichia coli at high frequencies which approach inter-Proteus transfer of the parental plasmids. The $\mathrm{P}-\mathrm{lac} \overline{\mathrm{R} 447 \mathrm{~b}}$ recombinant transfers $\mathrm{lac}^{+}$and only marker $\mathrm{K}$ of the parent $\mathrm{R}$ factor, at frequencies of P-lac inter-Proteus transfer. Both recombinants possess the compatibility property and possibly most other features of P-lac. Transductions of the P-lac $\overline{\mathrm{RI} d r d \mathrm{I} 9}$ recombinant with phages PL25 and 34 differ. Those with the former vector to P29 yield transductants which have markers ACKSu but not $\mathrm{lac}^{+}$or $\mathrm{S}$ and do not transmit markers conjugally. Conjugal transferability is restored with transductions of the recombinant to P29 carrying a resident P-lac; these transductants then transmit $l a c^{+} \mathrm{ACKSu}$ as a unit. Transductions of the recombinant P-lac $\overline{\mathrm{RI} d r d \mathrm{I} 9}$ with phage 34 to strains of $P$. mirabilis produce transductants which possess all the resistance determinants and which transfer these conjugally, but in which $\mathrm{lac}^{+}$does not appear. A spontaneous lac segregant of the P-lac $\overline{\mathrm{RI} d r d \mathrm{I} 9}$ recombinant retained the high transfer rate and other properties of the parent. Transduction of this segregant to strains of P29 and $P$. mirabilis resulted in transductants which carried markers ACKSu and ACKSSu respectively but could not transfer them by conjugation. Transductions of the segregant to strains harbouring P-lac again produced recombinant plasmids at low rates which transmitted the above groups of resistance determinants and $\mathrm{lac}^{+}$ at frequencies similar to those of the original recombinant. Transductions of the $\mathrm{P}-l a c \overline{\mathrm{R}} 447 \mathrm{~b}$ recombinant with either phage yielded transductants carrying $\mathrm{K}$ (and able to transmit it conjugally) but never any carrying $l a c^{+}$.

\section{N T ROD U C TION}

Recombination between $\mathrm{R}$ factors and plasmids not associated with resistance determinants has not been frequently reported. Harada, Kameda, Suzuki \& Mitsuhashi (1964) described a recombinant between F-lac and a non-transmissible $\mathrm{R}$ factor. In addition to possessing the drug-resistance marker of the $\mathrm{R}$ factor the recombinant had all the properties of F-lac. Watanabe \& Ogata (I966) investigated properties of a recombinant between an $\mathrm{R}$ factor and $\mathrm{F}$. The hybrid had features distinct from either parent. Kondo \& Mitsuhashi (1966) described a recombinant between a non-transferable $\mathrm{R}$ factor and $\mathrm{F}$. The recombinant had the properties of the $F$ component and the chloramphenicol resistance of the $\mathrm{R}$ factor. Gosden, Irving \& Bishop (I97I) described a sex factor FR 5 which is a 
recombinant of $F^{\prime} 8$ with $\mathrm{R}$ factor $\mathrm{R} I d r d \mathrm{I} 9$. This $\mathrm{R}$ factor is a mutant of the $f^{+} \mathrm{R}$ factor Ri (Meynell \& Datta, 1967) which lacks a functional represser of genes affecting transfer (Meynell \& Cooke, I969). FR5 carries the marker for galactose fermentation and all resistance determinants of RIdrdI9 apart from kanamycin. Cooper (I97I) described properties of a recombinant between a non-transmissible ColV and $\mathrm{R} 538 d r d \mathrm{I}$. The fused plasmid comprised the col determinant and transmissibility genes of the R factor. It appeared to have compatibility properties of both parents. Meynell (1973) mentions a recombinant of RIdrdig with F which produces sex pili of F not RI serotype.

Plasmids which carry $l a c^{+}$determinants may exist stably side by side with $\mathrm{R}$ factors, as demonstrated by Reeve (1970), Reeve \& Braithwaite (1970) and Brenchley \& Magasanik (1972), who isolated wild strains of Klebsiella aerogenes which carried both a $l a c^{+}$plasmid and drug resistance plasmids as separate entities.

Falkow, Wohlhieter, Citarella \& Baron (1964) demonstrated that a $l a c^{+}$determinant present in a strain of Proteus mirabilis isolated from clinical material (see Sutter \& Foecking, 1962) is associated with an infectious element and is readily transmissible to many other enterobacteria. The plasmid was named P-lac. The DNA of the plasmid has an average guanine plus cytosine molar content of $50 \%$ and a molecular weight of $10 \times 10^{6}$ (Wohlhieter, Falkow, Citarella \& Baron, 1964).

Proteus morganii strain I6 (Hedges, Datta, Coetzee \& Dennison, 1973) yielded a factor $\mathrm{R} 447 \mathrm{~b}$ of compatibility group $\mathrm{N}$ which is unique among wild $\mathrm{N}$ plasmids in that it confers kanamycin resistance. It does not confer host specificity type II on its hosts.

This paper describes the isolation and some properties of recombinants between P-lac and RIdrdi9 or R447b.

\section{METHODS}

Bacteria, plasmids and phages. These are listed in Table I. Streptomycin-resistant variants were selected by the method of Coetzee \& Sacks (1960). Mutants resistant to nalidixic acid were selected by the same method on agar containing $50 \mu \mathrm{g}$ nalidixic acid $/ \mathrm{ml}$.

Media. These were as previously used (Coetzee, Datta, Hedges \& Appelbaum, 1973) with the exception that the minimal medium contained $0.3 \%(\mathrm{w} / \mathrm{v})$ lactose instead of glucose and $0.01 \%(\mathrm{w} / \mathrm{v})$ tetrazolium chloride (Grabow, 1972). This medium was supplemented with amino acids $(20 \mu \mathrm{g} / \mathrm{ml})$ to suit auxotrophic strains when necessary.

Antibacterial drugs, conjugal transfer of plasmids, preparation of phage lysates and transduction techniques. These were as described by Coetzee et al. (1973), with the exception that streptomycin was used at $\mathrm{I} 5 \mu \mathrm{g} / \mathrm{ml}$ and also at $\mathrm{I} \mathrm{mg} / \mathrm{ml}$ for selection of chromosomally resistant organisms.

Propagation of F-specific phages. This was done according to the method of Haapala \& Falkow (I97I) with titration on Escherichia coli strain K 2 Hfrc.

Coexistence of plasmids and selection of bacteria in which segregation of plasmids had occurred. Plasmid-containing bacteria were grown overnight in broth and dilutions were plated on MacConkey agar and on this agar with antibiotics. Colonies on MacConkey agar were also replicated to this agar containing antibiotics. About 12000 colonies of each plasmid-containing strain were examined.

Effect of $F$ on transfer of $P$-lac. This was examined according to methods of Falkow et al. (1964). 
Table I. Bacteria, plasmids and phages

Bacteria

PMI 3

PMI 3str-r

PM5006

P29

E27nal-r

E. coli K I 2 strains:

HFrC

$\mathrm{J} 62$

J62-I

Plasmids and hosts

PMI $3(\mathrm{P}-l a c)$

PMI3(RIdrdI9)

PMI 3(RI-I)

PMI 3(R395)

P29(RIdrd 19)

P29str-r (R447b)

E. coli $\mathrm{K} 12$ 58-161
Properties*

Recipient for transducing phage 34 . $\mathrm{T}$ resistant

Recipient for transducing phage 34 .

$T$ resistant

Providence strain NCTC 9295. Recipient

for transducing phage PL25. A,T resistant

Escherichia coli recipient for $\mathrm{R}$ factors

met

$\mathrm{F}^{-l a c, \text { pro, his, trp }}$

J62nal-r mutant

Markers and compatibility group*

$\begin{array}{ll}l a c^{+} & \text {Undetermined } \\ \text { ACKSSu } & \text { FII } \\ \text { ACSSu } & \text { FII } \\ \text { ACSSpSut } h s p \text { II } & \text { N } \\ \text { ACKSSu } & \text { FII } \\ \text { AK } & \text { N } \\ \text { F }^{+} \text {lac met } & \text { FI }\end{array}$

Phages
34

PL25

$\mathrm{MS} 2$

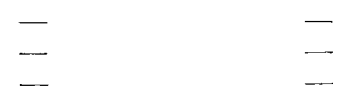

Reference or source

Coetzee \& Sacks (1960)

Coetzee \& Sacks (1960)

Coetzee \& Smit (1970)

Coetzee, Smit \& Prozesky (I966)

Coetzee et al. (1973)

Clowes \& Hayes (I968)

Clowes \& Hayes (1968)

Coetzee, Datta \& Hedges (1972)

Coetzee et al. (1973), Dr N. Datta

Coetzee et al. (1973)

Coetzee, Datta \& Hedges (I972)

Coetzee et al. (1973)

Datta \& Hedges (1972)

Hedges et al. (1973)

Clowes \& Hayes (1968), Falkow \& Baron (i962). lac obtained by u.v. irradiation

Coetzee \& Sacks ( 1960)

Coetzee et al. (1966)

Davis, Straus \& Sinsheimer (I96I)

* A, ampicillin; C, chloramphenicol; K, kanamycin; S, streptomycin; Su, sulphonamide; Sp, spectinomycin, $T$, tetracycline.

Table 2. Intra- and inter-strain transfer of plasmids

$\begin{array}{clcc}\text { Donor } & \text { Recipient } & \begin{array}{c}\text { Selected } \\ \text { marker }\end{array} & \begin{array}{c}\text { Transfer } \\ \text { frequency/donor } \\ \text { cell }\end{array} \\ \text { PMI3(P-lac) } & \text { PMI3str-r } & l a c^{+*} & 1 \times 10^{-1} \\ & \text { P29str-r } & l a c^{+*} & 8 \times 10^{-2} \\ \text { PMI3(RIdrd19) } & \text { P006str-r } & l a c^{+*} & 1 \times 10^{-1} \\ & \text { PM13nal-r } & \mathrm{K} \dagger & 1 \times 10^{-1} \\ \text { P29nal-r } & \mathrm{K} \dagger & 8 \times 10^{-2} \\ & \text { PM5006nal-r } & \mathrm{K} \dagger & 2 \times 10^{-1} \\ & \text { PM5006nal-r } & \mathrm{A} \dagger & 9 \times 10^{-4} \\ & \text { P29nal-r } & \mathrm{K} \dagger & 9 \times 10^{-4}\end{array}$

* Conjugal mixtures washed and plated on lactose minimal medium with streptomycin I mg/ml.

$\uparrow$ Selection on MacConkey agar containing nalidixic acid and appropriate antibiotic.

\section{R ES U L T S}

\section{Transfer of plasmids from strains of $\mathrm{PMI} 3$}

The rates at which P-lac and RIdrdI9 are transferred to strains of Proteus mirabilis and Providence are high and practically identical (Table 2). A strain of Salmonella typhosa carrying P-lac transfers it to lac strains of Escherichia coli at frequencies greater than $10^{\circ}$ donor cell while the transfer frequency between strains of E. coli is about $1^{-2}$ (Falkow 
Table 3. Transduction of $R \mathrm{I} d r d \mathrm{19}, R 447 b$ by phage $P L 25$

\begin{tabular}{|c|c|c|c|c|c|c|c|}
\hline \multicolumn{2}{|c|}{ Donor } & \multirow[b]{2}{*}{ Recipient } & \multirow{2}{*}{$\begin{array}{c}\text { Recipient } \\
\text { markers }\end{array}$} & \multirow{2}{*}{$\begin{array}{c}\text { Se- } \\
\text { lected } \\
\text { marker }\end{array}$} & \multirow{2}{*}{$\begin{array}{l}\text { Resistance } \\
\text { of trans- } \\
\text { ductants* }\end{array}$} & \multirow{2}{*}{$\begin{array}{c}\text { Transduc- } \\
\text { tion rate/ } \\
\text { adsorbed } \\
\text { p.f.u. }\end{array}$} & \multirow{2}{*}{$\begin{array}{c}\text { Conjugal } \\
\text { transfer } \\
\text { of } \\
\text { selected } \\
\text { marker } \dagger\end{array}$} \\
\hline Lysate & Resistance & & & & & & \\
\hline \multirow[t]{4}{*}{ P29(RIdrdI9) } & ACKSSuT & P29 & AT & S & ACKSSuT & $5 \times 10^{-8}$ & $0 / 19$ \\
\hline & & & & $\mathbf{K}$ & ACKSSuT & $9 \times 10^{-8}$ & $0 / 20$ \\
\hline & & & & $\mathrm{C}$ & ACKSSuT & $5 \times 10^{-8}$ & $0 / 20$ \\
\hline & & P29str-r(P-lac) & $\mathrm{AST} / a c^{+}$ & $\begin{array}{l}\mathrm{K} \\
\mathrm{C}\end{array}$ & $\begin{array}{l}\text { ACKSSuT: } \\
\text { ACKSSuT }\end{array}$ & $\begin{array}{l}8 \times 10^{-8} \\
8 \times 10^{-8}\end{array}$ & $\begin{array}{l}19 / 21 \\
15 / 15\end{array}$ \\
\hline P29nal-r(R447b) & $\mathrm{AKT}$ & & AT & $\mathbf{K}$ & AKT & $8 \times 10^{-7}$ & $20 / 20$ \\
\hline & & $\mathrm{P} 29$ str-r $(\mathrm{P}-\mathrm{lac})$ & AST $l a c^{+}$ & $\mathrm{K}$ & AKST & $8 \times 10^{-7}$ & $20 / 20$ \\
\hline
\end{tabular}

* Suspensions of purified transductants spotted on selective media.

$\uparrow$ Recipient Escherichia coli E27nal-r. Denominator refers to number of clones tested.

+ All clones $\mathrm{lac}^{+}$.

\section{Table 4. Conjugal transfer of transductant markers}

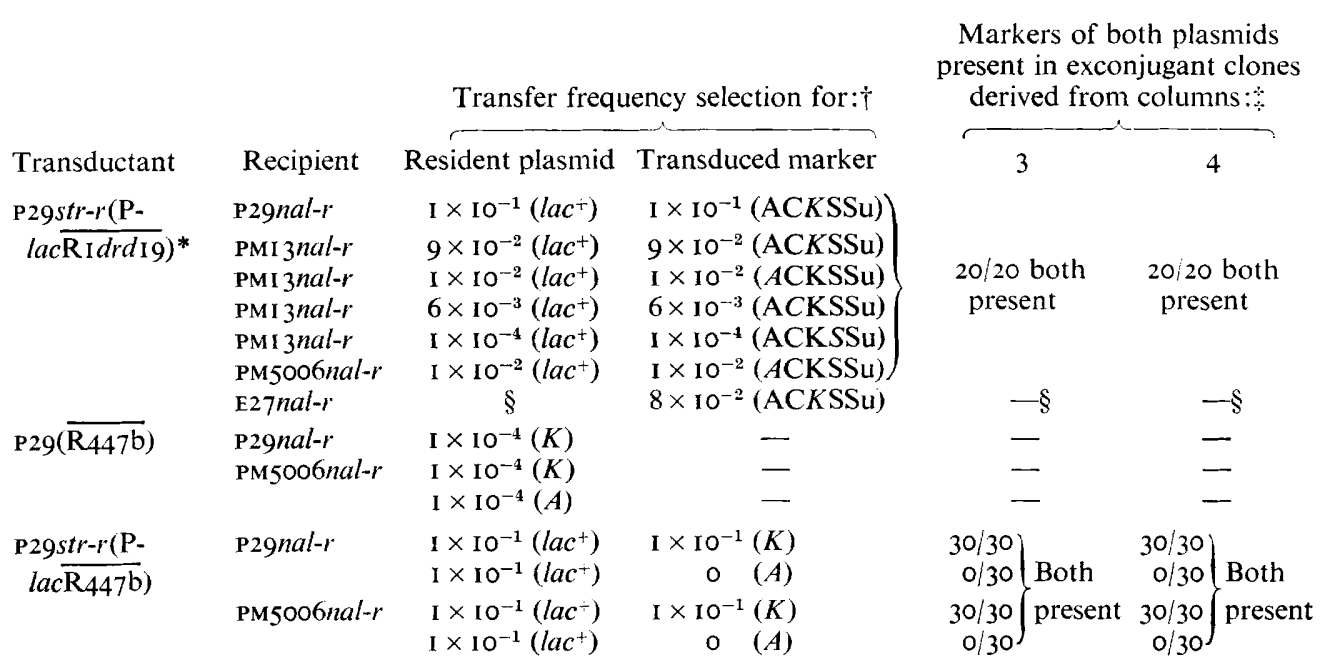

The italicized symbol in columns 3 and 4 is the marker used for selection. The remaining symbols in column 4 represent unselected markers detected by replication to appropriate media. lac ${ }^{+}$was selected on minimal medium. Drug resistance was selected on MacConkey agar containing individual antibiotics. Both media contained nalidixic acid.

* Superior line indicates transduced R factor.

$\uparrow$ Transfer frequency/donor cell.

$\leftarrow$ Denominator equals no. clones tested.

$\$$ E27nal-r is $l a c^{+}$.

et al. 1964). RIdrdI9 transfers at rates even higher than those presented here between strains of $E$. coli (Harden \& Meynell, I972). R447b transmits at very much lower frequencies which approximate to those of its inter-E. coli transfer (Hedges et al. 1973).

\section{Transduction of $R \mathrm{I} d r d \mathrm{I} 9$ and $R 447 b$ to Providence strain $\mathrm{P} 29$}

Preparations of phage PL25 on P29(RrdrdI9) and P29nal-r(R447b) had titres of I to $5 \times 10^{10}$ p.f.u. $/ \mathrm{ml}$. Table 3 shows results of transductions with these lysates. While all markers of RIdrdI9 which can be selected are transduced to P29 at low rates, transductants 
Table 5. Transduction of recombinant plasmids $P$-lac $\overline{R \mathrm{Idrd} \mathrm{r} 9}, P$-lac $\overline{R 447 b}$

\begin{tabular}{|c|c|c|c|c|c|c|c|c|c|}
\hline \multirow{2}{*}{$\begin{array}{c}\text { Expt } \\
\text { no. }\end{array}$} & \multicolumn{3}{|c|}{ Donor } & \multirow[b]{2}{*}{ Recipient } & \multirow{2}{*}{$\begin{array}{c}\text { Re- S } \\
\text { cipient } \\
\text { mar- } \\
\text { kers }\end{array}$} & \multirow{2}{*}{$\begin{array}{l}\text { Selec- } \\
\text { ted } \\
\text { mar- } \\
\text { ker }\end{array}$} & \multirow{2}{*}{$\begin{array}{c}\text { Markers } \\
\text { of } \\
\text { trans- } \\
\text { ductants }\end{array}$} & \multirow{2}{*}{$\begin{array}{l}\text { Trans- } \\
\text { duction } \\
\text { rate } \\
\text { (per } \\
\text { adsorbed } \\
\text { p.f.u.) }\end{array}$} & \multirow{2}{*}{$\begin{array}{l}\text { Con- } \\
\text { jugal } \\
\text { transfer } \\
\text { of } \\
\text { selected } \\
\text { marker }\end{array}$} \\
\hline & Phage & Lysate & Markers & & & & & & \\
\hline $\begin{array}{l}\text { I } \\
2 \\
3\end{array}$ & PL25 & $\mathrm{P} 29(\mathrm{P}-l a c \overline{\mathrm{RI} d r d \mathrm{I} 9})$ & ACKSSuTlac ${ }^{+}$ & P29 & AT & $\begin{array}{l}\mathbf{K} \\
\mathbf{C} \\
l a c^{+}\end{array}$ & $\begin{array}{l}\text { ACKSuT } \\
\text { ACKSuT } \\
\end{array}$ & $\begin{array}{c}5 \times 10^{-8} \\
5 \times 10^{-8} \\
0\end{array}$ & $\begin{array}{l}0 / 20^{*} \\
0 / 20^{*} \\
-\end{array}$ \\
\hline $\begin{array}{l}4 \\
5\end{array}$ & & & & P29(P-lac) & $\mathrm{AT} / a c^{+}$ & $+\underset{\mathbf{C}}{\mathbf{K}}$ & $\begin{array}{l}\text { ACKSuT } t \\
\text { ACKSuT }\end{array}$ & $\begin{array}{l}5 \times 10^{-9} \\
5 \times 10^{-9}\end{array}$ & $\begin{array}{l}10 / 10^{*} \\
10 / 10^{*}\end{array}$ \\
\hline $\begin{array}{l}6 \\
7\end{array}$ & 34 & PM5006(P-lac $\overline{\mathrm{RI} d r d \mathrm{I} 9})$ & ACKSSuTlac ${ }^{+}$ & PMI 3 & $\mathbf{T}$ & $\begin{array}{l}\mathrm{K} \\
\text { lac }^{+}\end{array}$ & $\begin{array}{c}\text { ACKSSuT } \\
-\end{array}$ & $\begin{array}{c}8 \times 10^{-8} \\
0\end{array}$ & $15 / 20 !$ \\
\hline $\begin{array}{l}8 \\
9\end{array}$ & PL25 & $\mathrm{P} 29(\mathrm{P}-l a c \overline{\mathrm{R} 447 \mathrm{~b}})$ & $\mathrm{AKT} l a c^{+}$ & P29 & AT & $\begin{array}{l}\mathbf{K} \\
\text { lac }^{+}\end{array}$ & $\stackrel{\mathrm{AKT}}{-}$ & $\begin{array}{c}\mathrm{I} \times \mathrm{IO}^{-8} \\
0\end{array}$ & $\begin{array}{c}20 / 20^{*} \\
-\end{array}$ \\
\hline $\begin{array}{l}\text { IO } \\
\text { II }\end{array}$ & 34 & PM5006(P-lac $\overline{\mathrm{R}}$ & $\mathrm{KT} l a c^{+-}$ & PM5006 & $\mathrm{T}$ & $\begin{array}{l}\mathrm{K} \\
\mathrm{A}\end{array}$ & $\mathrm{KT}_{-}$ & $\begin{array}{c}5 \times 10^{-8} \\
0\end{array}$ & $20 / 20 \dagger$ \\
\hline 12 & & & & & & $l a c^{-}$ & - & o & - \\
\hline
\end{tabular}

Methods were as for the experiments in Table 3. Selection for $l a c^{+}$was on minimal medium.

* Transfer to PMI 3 nal-r.

$\dagger$ Transfer to P29nal-r.

All clones $l a c^{\top}$.

cannot transmit the markers (Coetzee, 1972). These results differ from transductions of RIdrdI9 by phage 34 to strains of PMI 3 (Coetzee et al. I973). The latter transductants only registered markers $\mathrm{C}$ and $\mathrm{S}$. Transduction of $\mathrm{R} \mathrm{I} d r d \mathrm{I} 9$ into P29str-r(P-lac) yields transductants which transfer markers A, C, K, S and Su to Escherichia coli E27nal-r (Table 3). Table 4 reveals that $l a c^{+}$is also transferred to Proteus strains at the same high frequency as marker $\mathrm{K}$ and that all exconjugants have markers ACKSSu. The resident P-lac thus confers conjugal transmissibility to transductant markers of $\mathrm{RI} d r d \mathrm{I} 9$, and $l a c^{+}$invariably accompanies them. With selection for $\mathrm{A}, \mathrm{C}$ or $\mathrm{S}$ the frequency of transfer is decreased in that order, but all exconjugant clones carry $\mathrm{lac}^{+} \mathrm{ACKSSu}$ whatever the frequency of recovery of the drug marker. The apparent decrease in frequency of conjugal transfer of the complex with selection for markers $\mathrm{K}, \mathrm{A}, \mathrm{C}$ and $\mathrm{S}$ (in that order - Table 4) merely reflects differences in efficiency of expression of newly acquired genes by exconjugants. It is concluded that $\mathrm{P}-\mathrm{lac}$ and portions of transduced $\mathrm{R} \mathrm{I} d r d \mathrm{I} 9$ are closely associated in transductants. Both A and $\mathrm{K}$ markers of $\mathrm{R} 447 \mathrm{~b}$ are transmissible in P29 transductants (Table 4 ) but with a resident P-lac (Tables 3, 4) markers $\mathrm{lac}^{+}$and $\mathrm{K}$ (but not $\mathrm{A}$ ) register and are jointly transferred at the high frequency characteristic of P-lac. The complexes of $l a c^{+}$with RIdrdI9 and R447b respectively are readily transferred from nal-r exconjugant clones (including E27nal-r) to P29, PMI 3 and PM5006 as well as str-r variants of these strains and also strains of E. coli KI 2 without contraselection for the donor. The 34 transductant clones of P-lacR I drd I9 (Table 3) had the same phenotype. This also applies to the $20 \mathrm{P}-l a c \mathrm{R} 447 \mathrm{~b}$ clones investigated (Table 3).

\section{Transduction of P-lac $\overline{R \mathrm{I} d r d \mathrm{I} 9}$ and $P$-lac $\overline{R 447 b}$ complexes}

The $l a c^{-}$marker has not registered in transduction experiments with phage 34 lysates of PMI 3str-r(P-lac) or 5006str-r(P-lac) to PMI 3 and phage PL25 lysates of P29str-r(P-lac) to P29 with selection for $\mathrm{lac}^{+}$on minimal agar. These lysates transferred the $s t r-r$ chromosomal marker at high frequency (unpublished). Phage lysates were prepared of exconjugants 
PM5006(P-lac $\overline{\mathrm{RI} d r d \mathrm{I} 9})$, P29(P-lac $\overline{\mathrm{RI} d r d \mathrm{I} 9}), \quad \mathrm{P} 29(\mathrm{P}-l a c \overline{\mathrm{R} 447 \mathrm{~b}})$ and PM5006(P-lac $\overline{\mathrm{R} 447 \mathrm{~b}})$. Lysates had titres of at least $\mathrm{I} \times \mathrm{IO}^{10} \mathrm{p}$.f.u. $/ \mathrm{ml}$ and were used in the transduction experiments listed in Table 5. The $\mathrm{lac}^{+}$marker never registered either as a selected or an unselected marker. Markers ACKSu appear in P29 transductants at low frequencies but the latter do not transmit them in mating experiments (Table 5, Expts I, 2). These results differ from those of RIdrdI9 transductions to P29 listed in Table 3 in that the S marker is never expressed in the present transductants. By employing a resident P-lac, P29 transductants appeared at a low rate but all were infective for $\mathrm{lac}^{+} \mathrm{ACKSu}$ (Table 5, Expts 4, 5). Again the S marker does not register. These results may mean that PL25 only conveys ACKSu of the fused plasmid and that these are rendered transmissible by recombination with a resident $\mathbf{P}$-lac. Why the $\mathrm{S}$ marker is not found is not known as it is conveyed in transductions of the $\mathrm{R}$ factor. Phage 34-mediated transductants of the fused plasmid register all resistance determinants and are infective for them (Table 5, Expt 6). Again, marker $\mathrm{lac}^{+}$is not expressed in transductants. Transduction of the P-lac $\overline{\mathrm{R} 447 \mathrm{~b}}$ complex by both vectors is the same: neither markers $l a c^{+}$nor A register (Table 5, Expts 9, II) but transductants are conjugally infectious for $\mathrm{K}$ (Table 5, Expts 8, 10).

\section{Segregation of markers}

Overnight broth cultures of P29(P-lac $\overline{\mathrm{R} 447 \mathrm{~b}})$ and PM5006(P-lac $\overline{\mathrm{R} 447 \mathrm{~b}})$ plated on MacConkey agar containing kanamycin showed no pale colonies among about 12000 clones scanned. The same cultures plated on MacConkey agar had 10 and 16 pale colonies respectively per $\mathrm{I} 2000$ clones studied. All the $\mathrm{lac}^{+}$colonies on these plates replicated to kanamycin MacConkey agar but the pale clones did not transfer. Cultures of PM5006nal$r(\mathrm{P}-l a c \overline{\mathrm{RI} d r d \mathrm{I} 9}), \quad \mathrm{PMI} 3 n a l-r(\mathrm{P}-l a c \overline{\mathrm{RI} d r d \mathrm{I} 9}), \quad \mathrm{P} 29 n a l-r(\mathrm{P}-l a c \overline{\mathrm{RI} d r d \mathrm{I} 9})$ and $\mathrm{PM} 5006 s t r-r(\mathrm{P}-$ lac $\overline{\mathrm{R} I d r d \mathrm{I} 9})$ plated on MacConkey agar containing kanamycin or streptomycin did not produce pale colonies. The same cultures plated on MacConkey agar had I4, o, II and 3 pale colonies respectively per 12000 clones. $\mathrm{lac}^{+}$colonies on these plates grew when replicated to MacConkey agar containing kanamycin, ampicillin, chloramphenicol or streptomycin. The II pale clones from P29nal-r (P-lac $\overline{\mathrm{RI} d r d \mathrm{I} 9})$ were sensitive to $\mathrm{C}, \mathrm{K}, \mathrm{S}$ and Su. All I 4 pale clones derived from PM5006nal-r $(P-l a c \overline{\mathrm{RI} d r d \mathrm{I} 9})$ had lost markers ACKSSu. Two of the three pale clones derived from PM5006str-r(P-lac $\overline{\mathrm{RI} d r d \mathrm{I} 9})$ had also lost ACKSu resistance. The third pale clone retained resistance to these markers. These results demonstrate that the complexes, like components P-lac (Wohlhieter et al. I964), RIdrdI9 and R 447 b (unpublished), are stable in Proteus and that almost invariably all markers are lost simultaneously. The clone which had lost only the $l a c^{+}$marker is designated PM5006str- $r(\mathbf{P}-$ $\overline{\mathrm{RI} d r d \mathrm{I} 9})$ and differs from $\mathrm{P} 29(\overline{\mathrm{RI} d r d \mathrm{I} 9})$ and PMI3nal-r( $\overline{\mathrm{RI} d r d \mathrm{I} 9}$ ) (Coetzee et al. 1973) in that it is conjugally infective for markers ACKSSu at a frequency equal to that of the parent (data not shown). Phage lysates prepared on exconjugates of the segregant with PMI3nal-r and P29nal-r were used in transduction experiments to strains PM5006 and P29 respectively. Providence strain P29 transductants express markers ACKSu but are not infective for them (Table 6, Expts I, 2). Again the S marker is not expressed and results are similar to those of phage PL25 transductions of the parent recombinant. In experiments where the recipient carried $\mathrm{P}$-lac, transduction occurred at a low rate but all transductants were conjugally fertile for $\mathrm{lac}^{+} \mathrm{ACKSu}$ (Table 6, Expts 3, 4). Transduced markers of the segregant appear to have recombined with the resident P-lac. Results of phage 34 transductions of the segregant differ from those of the parent recombinant in that although all markers are transduced, transductants are not conjugally infective (Table 6, Expts 5 to 7). Conjugal fertility can be restored by employing P-lac as a resident (Table 6, Expts 8 to 10). Again the 
Table 6. Transduction of lac segregant of P-lac $\overline{R_{\mathrm{I}} d r d \mathrm{I} 9}$

\begin{tabular}{|c|c|c|c|c|c|c|c|c|c|}
\hline \multirow{2}{*}{\multicolumn{2}{|c|}{$\begin{array}{l}\text { Expt } \\
\text { no. Phage }\end{array}$}} & \multicolumn{2}{|l|}{ Donor } & \multirow[b]{2}{*}{ Recipient } & \multirow{2}{*}{\multicolumn{2}{|c|}{$\begin{array}{c}\text { cipient ted } \\
\text { mar- mar- } \\
\text { kers ker }\end{array}$}} & \multirow{2}{*}{$\begin{array}{l}\text { of } \\
\text { trans- } \\
\text { ductants }\end{array}$} & \multirow{2}{*}{$\begin{array}{l}\text { (per } \\
\text { adsorbed } \\
\text { p.f.u.) }\end{array}$} & \multirow{2}{*}{$\begin{array}{c}\text { of } \\
\text { selected } \\
\text { marker }\end{array}$} \\
\hline & & Lysate & Resistance & & & & & & \\
\hline $\begin{array}{l}\text { I } \\
2\end{array}$ & PL25 & P29nal-r(P-RIdrdI9 $)$ & ACKSSuT & P29 & $\mathrm{AT}$ & $\begin{array}{l}\mathrm{K} \\
\mathrm{C}\end{array}$ & $\begin{array}{l}\text { ACKSuT } \\
\text { ACKSuT }\end{array}$ & $\begin{array}{l}9 \times 10^{-8} \\
9 \times 10^{-8}\end{array}$ & $\begin{array}{l}0 / 20^{*} \\
0 / 18^{*}\end{array}$ \\
\hline $\begin{array}{l}3 \\
4\end{array}$ & & & & $\mathrm{P} 29(\mathrm{P}-\mathrm{lac})$ & ATlact & $\begin{array}{l}\mathrm{K} \\
\mathrm{C}\end{array}$ & $\begin{array}{l}\text { ACKSuT } \\
\text { ACKSuT }\end{array}$ & $\begin{array}{l}7 \times 10^{-9} \\
7 \times 10^{-9}\end{array}$ & $\begin{array}{l}18 / 18^{*} \\
15 / 15^{*}\end{array}$ \\
\hline $\begin{array}{l}5 \\
6 \\
7\end{array}$ & 34 & PM I 3 hal-r $(\mathrm{P}-\overline{\mathrm{RI} d r d 19}$ & ACKSSuT & PM5006 & $\mathrm{T}$ & $\begin{array}{l}\mathrm{A} \\
\mathrm{K} \\
\mathrm{C}\end{array}$ & $\begin{array}{l}\text { ACKSSuT } \\
\text { ACKSSuT } \\
\text { ACKSSuT }\end{array}$ & $\begin{array}{l}\mathrm{I} \times 10^{-7} \\
\mathrm{I} \times 10^{-7} \\
\times 10^{-7}\end{array}$ & $\begin{array}{l}0 / 20 t \\
0 / 20 t \\
0 / 20 \dagger\end{array}$ \\
\hline $\begin{array}{r}8 \\
9 \\
10\end{array}$ & & & & PM5006(P-lac) & Tlac ${ }^{\dagger}$ & $\begin{array}{l}\mathrm{A} \\
\mathrm{K} \\
\mathrm{C}\end{array}$ & $\begin{array}{l}\text { ACKSSuT } \\
\text { ACKSSuT } \\
\text { ACKSSuT }\end{array}$ & $\begin{array}{l}6 \times 10^{-9} \\
6 \times 10^{-9} \\
6 \times 10^{-9}\end{array}$ & $\begin{array}{l}\text { I } 4 / 14 \dagger \\
\text { I } 5 / 15 \dagger \\
13 / 13 \dagger\end{array}$ \\
\hline
\end{tabular}

Methods were as for the experiments in Table 3.

* Transfer to PM5006nal-r. † Transfer to P29nal-r. $\$$ All clones were $l a c^{\dagger}$.

transduced segregant plasmid fragment appears to have recombined with P-lac. The fused plasmids have the high transmissibility rates of the original recombinant, the resistance markers and $\mathrm{lac}^{+}$being invariably transferred together; the only difference is that the plasmids derived from phage PL25 transductions do not possess the S marker (data not shown)

\section{Effect of $F$ on conjugal transfer of the fusion plasmid}

The presence of $\mathrm{F}$ in a lac strain 58-16 $\mathrm{I}$ of Escherichia coli $\mathrm{KI} 2$ also harbouring the fused plasmids P-lac $\overline{\mathrm{R} I d r d \mathrm{I} 9}$ or P-lac $\overline{\mathrm{R} 447 \mathrm{~b}}$ reduces their transfer by about Iooo-fold. Similar results have been reported in experiments where $\mathrm{P}$-lac is present in E. coli $\mathrm{F}^{+}$strains (Falkow et al. 1964).

Superinfection immunity of P-lacR $\mathrm{I} d r d \mathrm{I} 9$, its lac segregant and P-lacR $447 b$

Table 7 shows that the frequency of transfer of the P-lac $\overline{\mathrm{RI} d r d \mathrm{I} 9}$ complex and its $l a c$ segregant to recipients which carry a resident P-lac is reduced 1000-fold or more in comparison with transfer to strains not carrying the latter plasmid or strains harbouring $\mathrm{R}_{\mathrm{I}-\mathbf{I}}$. The fused plasmid P-lac $\overline{\mathrm{R} 447 \mathrm{~b}}$ is also excluded by P-lac. Exclusion by P-lac is not complete, as happens between I-like factors, but resembles $\mathrm{N}$ plasmids where the frequency of transfer to a cell carrying a resident of the same compatibility group is greatly reduced (Datta \& Hedges, 1971). It is concluded that both complexes and the lac segregant have the surface exclusion properties of P-lac. Stable coexistence of the plasmids was tested in Expts 5 to 8, Io and 1 I of Table 7. In Expt 5 no pale chloramphenicol resistant segregants were observed, while many pale kanamycin resistant clones were obtained from exconjugants of Expt 6 . These experiments suggest that P-lac $\overline{\mathrm{R} I d r d \mathrm{I} 9}$ coexists stably with $\mathrm{R}_{\mathrm{I}-\mathrm{I}}$ but not with its $l a c$ segregant and it may be inferred (Meynell, I969) that the recombinant and its segregant belong to the same compatibility group. Expt 7 never yielded kanamycin-sensitive clones while Expt 8 produced many lac colonies resistant to kanamycin. Results of the latter conjugation experiment differ from those of transduction experiments reported in Table 6 (Expts 8, 9): although transduction rates were more than tenfold lower than those to non-Plac-carrying recipients, pale clones were not observed. Many $\mathrm{lac}^{+}$kanamycin sensitive clones were segregated by exconjugants derived from Expt Io. Cultures derived from Expt I I 
Table 7. Frequency of transfer

\begin{tabular}{|c|c|c|c|c|c|}
\hline & & & $\begin{array}{l}\text { Com- } \\
\text { patibility } \\
\text { group of }\end{array}$ & Transfe & quency \\
\hline Donor & no. & Recipient & plasmid & $l a c^{+*}$ & $\mathrm{~K} \dagger$ \\
\hline $\mathrm{PMI} 3 n a l-r\left(\mathrm{P}-l a c \overline{\mathrm{R} 1 d r d_{19}}\right)$ & 1 & PMI 3str-r (P-lac) & $?$ & - & $5 \times 10^{-7}$ \\
\hline & 2 & PMI $3 s t r-r$ & - & $8 \times 10^{-2}$ & $8 \times 10^{-2}$ \\
\hline & 3 & $\mathrm{P} 29$ str-r $(\mathrm{P}-l a c)$ & $?$ & - & $5 \times 10^{-7}$ \\
\hline & 4 & P29str-r & - & $8 \times 10^{-2}$ & $8 \times 10^{-2}$ \\
\hline & 5 & PMI $3 \operatorname{str}-r(\mathrm{RI}-\mathrm{I})$ & F II & $5 \times 10^{-2}$ & $5 \times 10^{-2}$ \\
\hline & 6 & PM5006str-r $(\mathrm{P}-\widehat{\mathrm{R} I d r d \mathrm{I} 9})$ & $?$ & $5 \times 10^{-7}$ & - \\
\hline PM5006nal-r(P-Ridrdi9 $)$ & 7 & PMI3str-r(RI-I) & F II & - & $5 \times 10^{-2}$ \\
\hline & 8 & PMI 3str-r(P-lac) & $?$ & - & $\mathrm{I} \times \mathrm{IO}^{-7}$ \\
\hline & 9 & PMI $3 s t r-r$ & - & - & $9 \times 10^{-2}$ \\
\hline PM5006(P-lac $\overline{\mathrm{R} 447 \mathrm{~b}})$ & 10 & PMI $3 s t r-r(\mathrm{P}-l a c)$ & $?$ & - & $\mathrm{I} \times 1 \mathrm{IO}^{-6}$ \\
\hline & II & PM13str-r(R395) & $N$ & $8 \times \mathrm{IO}^{-2}$ & $8 \times 10^{-2}$ \\
\hline
\end{tabular}

Due to marker overlap transfer frequency of both markers was not always determined.

* Selection for $\mathrm{lac}^{+*}$ was also on minimal medium with $\mathrm{S}$ ( $\left.\mathrm{I} \mathrm{mg} / \mathrm{ml}\right)$.

$\dagger$ Selection on MacConkey agar with $\mathrm{K}$ and $\mathrm{S}$ ( $\mathrm{I} \mathrm{mg} / \mathrm{ml})$.

yielded colonies which were almost all $l a c^{\dagger}$ on MacConkey agar, which all replicated to this agar containing kanamycin and chloramphenicol. Expts Io and II thus suggest that $\mathrm{P}-\mathrm{lac} \overline{\mathrm{R} 447 \mathrm{~b}}$ is compatible with an $\mathrm{N}$ plasmid but not with P-lac.

\section{Bacteriophage propagation}

Phage MS2 did not increase in p.f.u. when incubated with strains of PMI3(P-lac), P29nal$r(\mathrm{P}-l a c)$, PMI3 $(\overline{\mathrm{RI} d r d \mathrm{I} 9}), \quad \mathrm{P} 29(\overline{\mathrm{RI} d r d \mathrm{I} 9})$ P29str-r(P-lac $\overline{\mathrm{RI} d r d \mathrm{I} 9}), \mathrm{PMI}$ nal-r(P-lac $\overline{\mathrm{RI} d r d \mathrm{I} 9})$, PM5006str-r $\left(\mathrm{P}-\overline{\mathrm{RI}_{\mathrm{I}} d_{r} d_{19}}\right) \mathrm{P} 29$ nal-r $\left(\mathrm{P}-\overline{\mathrm{R} I d_{r} d_{\mathrm{I}}}\right)$ or fertile exconjugants from Expts 6,8 and Io of Table 5. Control mixtures of the phage and PMI3(RIdrdig) showed at least a Io ooo-fold increase in titre. These results confirm those of Falkow et al. (I964) for P-lac and demonstrate that neither transductants of $\mathrm{RI} d r d \mathrm{I} 9$ nor the plasmid complex or its segregant or organisms harbouring the $\mathrm{P}-l a c \overline{\mathrm{R}} 447 \mathrm{~b}$ complex are susceptible to the F-specific phage.

\section{DISCUSSION}

The P-lac plasmid is stable in Proteus mirabilis (Wohlhieter et al. 1964) and in Providence strain P29 (unpublished). RIdrdI9 is unstable in P29 (unpublished) but segregation studies show that the complex of the two factors is remarkably stable in P29 and in P. mirabilis exconjugants. R447b is stable in Providence and $P$. mirabilis. The complex P-lac $\overline{\mathrm{R} 447 \mathrm{~b}}$ retains this characteristic. Stability of the associations was a feature from the onset. The complexes were discovered during an investigation of transduction of $\mathrm{R}$ factors by phage PL25 (unpublished) and differ from the association between RIdrd 9 and Fgal which was unstable initially (Gosden et al. 1971). A feature which accords well with recombination between the plasmids is that apart from one segregant of P-lac $\overline{\mathrm{RI} d r d \mathrm{I} 9}$ all markers of the complexes are lost simultaneously.

Cells harbouring the recombinant plasmids, like Proteus carrying only P-lac (Falkow et al. 1964) or strain 29 transductants of R Idrd I9 or R447b, do not permit MS2 multiplication. The nature of sex pili, if any, formed by the complexes is not known and attempts to isolate phages specific for organisms carrying P-lac or the complexes have not succeeded to 
date. It is not known whether P-lac causes specific surface changes in cells carrying it. The fact that cells harbouring recombinants do not support phage MS2 multiplication is no argument for inferring that recombinant plasmids have the surface modifying properties of P-lac. Alfaro \& Willetts (1972) found that transfer systems of F-like plasmids did not necessarily correspond to their compatibility properties. The fused plasmids have the compatibility properties of P-lac, not RIdrdI9 or $\mathrm{N}$ (Table 7), and transfer at frequencies approaching that of intra-strain passage of the former plasmid. The lac segregant of the Plac $\overline{\mathrm{R} I d r d \mathrm{I} 9}$ fused plasmid differs from parent $\mathrm{R} I d r d \mathrm{I} 9$ in that it does not confer phage MS2 sensitivity on its host and - like the complex - does not exclude RI $d r d$ I9. Although the presence of P-lac does not interfere with the functions of F, transfer of P-lac from strains carrying $\mathrm{F}$ is markedly inhibited (Falkow et al. 1964). The nature of the interaction is not known but may not necessarily implicate a specific represser (see also Meynell, 1973). The inhibition of transfer of the P plasmid RP4 by the I-like factor R64 in established cultures may be a similar phenomenon (Datta et al. 197I) and probably means that the regulation of fertility is more complex than a simple represser-operator interaction (Clowes, 1972).

The fact that the complexes described here differ in some genetic properties from the ancestors, and that the lac segregant of $\mathrm{P}-l a c \overline{\mathrm{R} I d r d \mathrm{I} 9}$ also differs from its parents, favours genetic recombination between the plasmids rather than a mere physical association. The recombinant between an $\mathrm{R}$ factor and $\mathrm{F}$ described by Watanabe \& Ogata (I966) had the high transmissibility and compatibility properties of $F$, was susceptible to F-specific phages but differed from $F$ in that it was not eliminated by acridines and did not restrict a particular phage. It differed from the parent $\mathrm{R}$ factor by not suppressing F-mediated fertility. Watanabe and Ogata explained features of the recombinant on the grounds that transfer of the complex is still mediated by $F$, but that the acridine sensitivity and phage restriction regions of the latter DNA were simply replaced by the $\mathrm{R}$ factor.

Apart from physical studies (Nisioka, Mitani \& Clowes, 1970) one of the surest ways of demonstrating recombination between plasmids is joint transduction of markers (Clowes, 1972). With the use of phage PI, Mitsuhashi et al. (1962), Watanabe \& Lyang (1962), Harada, Kameda, Suzuki \& Mitsuhashi (I964), Watanabe et al. (I964), Hashimoto \& Hirota (I966), Kondo \& Mitsuhashi (I966) and Kameda, Harada, Suzuki \& Mitsuhashi (I969) demonstrated co-transduction of markers from different plasmids and suggested that they recombined. Watanabe \& Ogata (1966) could not transduce a complex of an $\mathrm{R}$ factor and $\mathrm{F}$ with phage $\mathrm{PI}_{\mathrm{I}}$ although it had features of a recombinant. The failure of phages 34 and PL 25 to transduce all markers of the fusion plasmids reported here may possibly be explained by the magnitudes of the molecular weights of the plasmids concerned. The mol. wt of phage PL25 DNA is $24.7 \times 10^{6}$ daltons and that of phage 34 is $29.5 \times 10^{6}$ daltons (van Rensburg, 1970). The mol. wt of P-lac is only $10 \times 10^{6}$ (Wohlhieter et al. 1964) but the composite molecule of RIdrdI9 has a mol. wt of $65 \times 10^{6}$ daltons (Cohen \& Miller, 1969; Silver \& Falkow, 1970) of which the transfer element contributes $52 \times 10^{6}$ daltons and the resistance determinant replicon the remainder (Cohen \& Miller, 1970; Haapala \& Falkow, I97I). The mol. wt of R447b is not known. The contributions of the two parents to the two fusion plasmids is not known, but complexes may have weights too large for these vectors to accommodate. The PL25 vector can contain all resistance determinants of R IdrdI9 (Table 3) but only markers ACKSu of the complex are expressed in transductants of the phage (Table 5, Expts I, 2). It may mean that due to the structure of the complex only these markers can be taken up by the phage or, if markers $\mathrm{S}$ or $l a c^{+}$are also conveyed, only genes of the former cluster are assembled in a non-transferable replicon or are incorporated in the bacterial chromosome (Coetzee et al. 1973). The fact that only the 
ACKSu cluster recombines with a resident P-lac to form a highly transferable plasmid (Expts 3, 4, Table 6) may favour the view that only the latter cluster of the complex is conveyed by vector PL25. Phage 34 transduction of the complex results in transductants which register all resistance determinants (but not $l a c^{+}$) and are conjugally infectious (Table 5, Expt 6). The vector may thus be able to select (and convey) a transferable replicon from the genes of the complex. Results differ from those of Coetzee et al. (1973) where, although P-lac was not employed as a resident, only $\mathrm{C}$ and $\mathrm{S}$ markers registered in transductants by phage 34. P-lac was, however, used with phage 7 . R49 transductions of RIdrd 19 to Proteus rettgeri strain $\mathrm{R} 49$ but resistance determinants did not register. Transduction of $\mathrm{R} 447 \mathrm{~b}$ by phage PL25 differs from those of RIdrdI9 by the same vector in that transductants are conjugally infectious for the resistance determinants (Tables 3,4 ). R447b is quite stable in P29 and it is surprising that total recombination between it and P-lac was obtained on first attempt, as there is no pressure to mobilize the genes as in the case of RIdrdI9 determinants in strain P29 or in E. coli with Fgal (Gosden et al. 197I). Transduction of R447b by phage 34 to PMI3 (Coetzee et al. 1973) yielded transductants which were only infectious for marker A while transduction to PMI 3 harbouring P-lac did not yield recombinant plasmids at first attempt and the experiments were not pursued. Transduction of the recombinant $\mathrm{P}-\mathrm{lac} \overline{\mathrm{R} 447 \mathrm{~b}}$ by both phages yielded results which resemble transductions of recombinant P-lac $\overline{\mathrm{RI} d r d \mathrm{I} 9}$ by phage 34 , in the sense that although transductants do not register $\mathrm{lac}^{+}$ they do claim enough of the transduced material to constitute independent transmissible plasmids for the resistance determinants carried by the two recombinants respectively.

The lac segregant of the P-lac $\overline{\mathrm{RI} d r d \mathrm{I} 9}$ complex behaves in an identical fashion to the parent recombinant as far as the PL25 vector is concerned (Table 5, Expts I to 5; Table 6, Expts I to 4), and the conclusion may be that its genes retain the steric relationship of the complex and the lac phenotype is not caused by a deletion. However, the phage 34 vector produces transductants of the segregant which are non-infectious for the resistance determinants (Table 6, Expts 5 to 7), unlike transductants of the complex (Table 5, Expt 6), and the segregant may thus have a disturbed structure. It is as if the vectors employed have a preference for the resistance determinant region no matter whether these are carried by the $\mathrm{R}$ factors, recombinant or segregant. This region has a ready partner in the resident P-lac with which it may recombine to form a transmissible plasmid.

An explanation to accommodate features of the association described may be that vector PL25 conveys only the resistance determinant regions of the $R$ factors to P29. This material then integrates into the resident P-lac and transfer of the complex is mediated under control of P-lac transfer genes. This is an adequate explanation for the P-lac $\overline{\mathrm{R}} 447 \mathrm{~b}$ recombinant because it transfers at the same high rate as the P-lac parent. The P-lac $\overline{\mathrm{RI} d r d \mathrm{I} 9}$ recombinant transfers at a rate similar to both parents, and the possibility that transfer genes of RIdrdI9 may participate in transmission of the complex cannot be excluded.

This work was supported by grants from the South African Medical Research Council.

\section{REFERENCES}

Alfaro, G. \& Willetts, N. (1972). The relationship between the transfer systems of some bacterial plasmids. Genetical Research 20, 279-289.

Brenchley, J. E. \& MAGASANIK, B. (1972). Klebsiella aerogenes strain carrying drug-resistance determinants and a lac plasmid. Journal of Bacteriology $\mathbf{1 2}$, 200-205.

CLOWES, R. C. (1972). Molecular structure of bacterial plasmids. Bacteriological Reviews 36, 36I-405.

Clowes, R. C. \& Hayes, W. (1968). Experiments in Microbial Genetics. Oxford and Edinburgh: Blackwell Scientific Publications. 
Coetzee, J. N. (1972). Genetics of the Proteus group. Anmual Review of Microbiology 26, 23-54.

Coetzee, J. N., Datta, N. \& Hedges, R. W. (1972). R Factors from Proteus rettgeri. Journal of General Microbiology 72, 543-552.

Coetzee, J. N., Datta, N., Hedges, R. W. \& Appelbaum, P. C. (1973). Transduction of R factors in Proteus mirabilis and $P$. rettgeri. Journal of General Microbiology 76, 355-368.

Coetzee, J. N. \& Sacks, T. G. (1960). Transduction of streptomycin resistance in Proteus mirabilis, Journal of General Microbiology 23, 445-455.

Coetzee, J. N. \& SMit, J. A. (1970). Properties of Proteus mirabilis phage I 3 vir. Journal of General Virology 9, $247-249$.

Coetzee, J. N., Smit, J. A. \& Prozesky, O. W. (1966). Properties of Providence and Protels morganii transducing phages. Journal of General Microbiology 44, 167-176.

Cohen, S. N. \& Miller, C. (1969). Multiple molecular species of circular R-factor DNA isolated from Escherichia coli. Nature, London 224, I273-1277.

Cohen, S. N. \& Miller, C. (1970). Non-chromosomal antibiotic resistance in bacteria. III. Isolation of the discrete transfer unit of the R-factor R I. Proceedings of the National Academy of Sciences of the United States of America 67, 510-516.

COOPER, P. (197I). Interaction of a colicinogenic factor with a resistance factor and with the fertility factor $F$ in Escherichia coli K-12. Genetical Research 17, 151-159.

Datta, N. \& Hedges, R. W. (197I). Compatibility groups among $f i^{-}$R factors. Nature, London 234, $222-223$.

Datta, N. \& Hedges, R. W. (1972). Host ranges of R factors. Journal of General Microbiology 70, 453-460.

Datta, N., Hedges, R. W., Shaw, E. J., Sykes, R. B. \& Richmond, M. H. (I97I). Properties of an R factor from Pseudomonas aeruginosa. Journal of Bacteriology 108, I244-1 249.

Davis, J. E., Straus, J. H. \& Sinsheimer, R. L. (196I). Bacteriophage $\mathrm{MS}_{2}$ : another RNA phage. Science, New York r34, I427.

Falkow, S. \& Baron, L. S. (1962). Episomic element in a strain of Salmonella typhosa. Journal of Bacteriology 84, 58I-589.

Falkow, S., Wohlhieter, J. A., Citarella, R. V. \& Baron, L. S. (1964). Transfer of episomic elements to Proteus. Journal of Bacteriology 88, I598-I60I.

Godsen, J. R., IRVING, M. I. \& BIshop, J. O. (I97I). Galactose-specific messenger ribonucleic acid content in Escherichia coli. Biochemical Journal I21, 109-1 16.

Grabow, W. O. K. (1972). Growth-inhibiting metabolites of Proteus mirabilis. Journal of Medical Microbiology 5, I9I-196.

Haapala, D. K. \& Falkow, S. (I97I). Physical studies of the drug-resistance transfer factor in Proteus. Journal of Bacteriology 106, 294-295.

Harada, K., Kameda, M., Suzuki, M. \& Mitsuhashi, S. (1964). Drug resistance of enteric bacteria. III. Acquisition of transferability of nontransmissible R(TC) factor in cooperation with $F$ factor and formation of FR(TC). Journal of Bacteriology 88, I257-I 265.

HARden, V. \& MEYNell, E. (I972). Inhibition of gene transfer by antiserum and identification of serotypes of sex pili. Journal of Bacteriology 109, 1067-1074.

Hashimoto, H. \& HiRota, Y. (1966). Gene recombination and segregation of resistance factor R in Escherichia coli. Journal of Bacteriology 9r, 51-62.

Hedges, R. W., Datta, N., Coetzee, J. N. \& Dennison, S. (I973). R factors from Proteus morganii. Journal of General Microbiology 77, 249-259.

Kameda, M., Harada, K., Suzuki, M. \& Mitsuhashi, S. (1969). Formation of transferable drug resistance factor by recombination between resistance determinants and transfer factors. Japanese Joumal of Microbiology $\mathbf{1 3}, 255^{-262}$.

Kondo, E. \& Mitsuhashi, S. (I966). Drug resistance of enteric bacteria. VI. Introduction of bacteriophage PICM into Salmonella typhi and formation of PIdCM and F-CM elements. Journal of Bacteriology 9r, $1787-1794$.

Meynell, E. (I973). Pseudo- $f$ I-like sex factor, R 62(I), selective for increased pilus synthesis. Journal o, Bacteriology 113, 502-503.

Meynell, E. \& CoOKe, M. (I969). Repressor-minus and operator-constitutive de-repressed mutants of $F$-like $\mathrm{R}$ factors: their effect on chromosomal transfer by HfrC. Genetical Research 14, 309-3I 3.

Meynell, E. \& Datta, N. (1967). Mutant drug resistant factors of high transmissibility. Nature, London 214, $885-887$.

Meynell, G. G. (I969). Exclusion, superinfection immunity and abortive recombinants in $\mathrm{I}^{+} \times \mathrm{I}^{-}$bacterial crosses. Genetical Research $\mathbf{1 3}_{3}, \mathrm{II}_{3}-115$. 
Mitsuhashi, S., Harada, K., Hashimoto, H., Kameda, M. \& Suzuki, M. (I962). Combination of two types of transmissible drug-resistance factors in a host bacterium. Journal of Bacteriology 84, 9-16.

Nisioka, T., Mitani, M. \& Clowes, R. C. (I970). Molecular recombination between R-factor deoxyribonucleic acid molecules in Escherichia coli host cells. Journal of Bacteriology 103, I66-I 77.

REEVE, E. C. R. (1970). Transfer characteristics of two resistance determinants in a wild strain of Klebsiella aerogenes (v9A). Genetical Research 16, 235-240.

Reeve, E. C. R. \& Braithwaite, J. A. (1970). F $\mathbf{F}_{\mathbf{k}}$ lac, an episome with unusual properties found in a wild strain of a Klebsiella species. Nature, London 228, I62-I64.

van Rensburg, A. J. (I970). Studies on Proteus and Providence spheroplasts, L-forms and bacteriophage nucleic acids. M.D. Thesis, University of Pretoria.

Silver, R. P. \& FAlkow, S. (I970). Specific labelling and physical characterization of R-factor deoxyribonucleic acid in Escherichia coli. Journal of Bacteriology 104, 33 I-339.

Sutter, V. L. \& Foecking, F. J. (I962). Biochemical characteristics of lactose-fermenting Proteus rettgeri from clinical specimens. Journal of Bacteriology 83, 933-935.

WATANABE, T. \& LYANG, K. W. (1962). Episome-mediated transfer of drug resistance in Enterobacteriaceae. $\mathrm{V}$. Spontaneous segregation and recombination of resistance factors in Salmonella typhimurium. Journal of Bacteriology 84, 422-430.

Watanabe, T., Nishida, H., Ogata, C., Arai, T. \& Sato, S. (I964). Episome-mediated transfer of drug resistance in Enterobacteriaceae. VII. Two types of naturally occurring R factors. Journal of Bacteriology 88, 7 1 6-726.

Watanabe, T. \& Ogata, C. (I966). Episome-mediated transfer of drug resistance in Enterobacteriaceae. IX. Recombination of an R factor with F. Journal of Bacteriology 9I, 43-50.

Wohlhieter, J. A., Falkow, S., Citarella, R. V. \& Baron, L. S. (I964). Characterization of DNA from a Proteus strain harboring an episome. Journal of Molecular Biology 9, 576-588. 